\title{
Solar Photo-Fenton Degradation of Electro-Optical Industry Wastewater by a Pilot-Scale Fresnel Lens Assisted IPCC Reactor
}

\author{
Wen-Shiuh Kuo, Dong-Yun Liu, and Chin-Fang Juang \\ Department of Safety, Health, and Environmental Engineering, National United University, Miao-Li 360, Taiwan \\ Correspondence should be addressed to Wen-Shiuh Kuo; wsk@nuu.edu.tw
}

Received 10 August 2013; Revised 23 October 2013; Accepted 14 November 2013

Academic Editor: M. Swaminathan

Copyright (c) 2013 Wen-Shiuh Kuo et al. This is an open access article distributed under the Creative Commons Attribution License, which permits unrestricted use, distribution, and reproduction in any medium, provided the original work is properly cited.

\begin{abstract}
In this study, a pilot-scale Fresnel lens mounted inclined plate curvature channel (IPCC) solar photo-Fenton reactor was well designed, established, and evaluated for the treatment of the electro-optical industry wastewater. Under an initial $\mathrm{pH}$ of 3.0, a $\left[\mathrm{H}_{2} \mathrm{O}_{2}\right]_{0} / \mathrm{COD}_{0}$ ratio of 2 , and a $\left[\mathrm{H}_{2} \mathrm{O}_{2}\right]_{0} /\left[\mathrm{Fe}^{2+}\right]_{0}$ ratio of 7.5 for a reaction time of $60 \mathrm{~min}$, the COD of the wastewater could reach a reduction of $85-90 \%$ which meets the effluent standard of EPA, Taiwan (COD < 100 mg/L). In addition, it was found that solar light could be concentrated, which resulted in an increase in $\mathrm{UV}_{\mathrm{a}+\mathrm{b}}$ intensity for 1.89 to 3.76 times and the temperature of the wastewater could be raised for 8 to $16^{\circ} \mathrm{C}$. Therefore, the residual COD of the electro-optical industry wastewater was also kept under $100 \mathrm{mg} / \mathrm{L}$ after a $60 \mathrm{~min}$ of treatment even in winter season. Furthermore, the microtoxicity of the wastewater was essentially removed. Accordingly, these results illustrated that the IPCC reactor showed a synergistic effect on the solar photo-Fenton process not only in effectively dealing with a large amount of industrial organic wastewater, but also in the sector of energy conservation in terms of effective utilization of solar energy.
\end{abstract}

\section{Introduction}

Organic wastewater from the electro-optical industry generally contains so many residuals such as TMAH $\left(\mathrm{C}_{4} \mathrm{H}_{13} \mathrm{NO}\right)$, PGMEA $\left(\mathrm{C}_{6} \mathrm{H}_{12} \mathrm{O}_{3}\right)$, acrylic resin, and pigments and it is variable in composition and strength at different stages of process. The effluent is usually characterized as a high chemical oxygen demand (COD) of wastewater. Therefore, biological treatment processes are susceptible for treatment of electro-optical industry wastewater. Instead, activated carbon adsorption or coagulation is commonly used. However, new environmental laws may consider the spent adsorbents or sludge as hazardous waste and require further treatment. Consequently, intensive research for novel technologies with higher efficiency and less amount of waste generated has been stimulated. For that reason, advanced oxidation processes (AOPs) have been previously described as a promising option to remove persistent pollutants from contaminated water [1] when conventional water treatment processes are not efficient enough. AOPs are able to produce a highly reactive, nonspecific oxidant, mainly hydroxyl radicals $\left({ }^{\circ} \mathrm{OH}\right)$. The hydroxyl radical possesses inherent properties that enable it to attack refractory organic pollutants in water to achieve a complete mineralization. However, the production of photons with artificial light sources requires significant electrical energy demand and UV lamp consumption, leading in a high operation cost in AOPs [2].

Alternatively, solar energy is essentially unlimited and its utilization is ecologically benign. In the wastewater treatment sector, solar technology has been extensively used as alternative to UV lamps to reduce the operation cost in AOPs [3]. In particular, photo-Fenton process (1)-(3) using solar irradiation has been used as an economically viable process and has attracted great interest in recent years [4]. However, solar photo-Fenton process was usually carried out by using solar irradiation directly, resulting in a lower absorption and utilization of solar energy [5]. To improve the efficiency and actual practice of solar photo-Fenton process, it is necessary to maximize the absorption of solar energy for process reactor. Hence, a solar light concentrated compound parabolic collector (CPC) was effectively used to treat landfill leachate in the study of Vilar et al. [6]. Additionally, Fresnel 


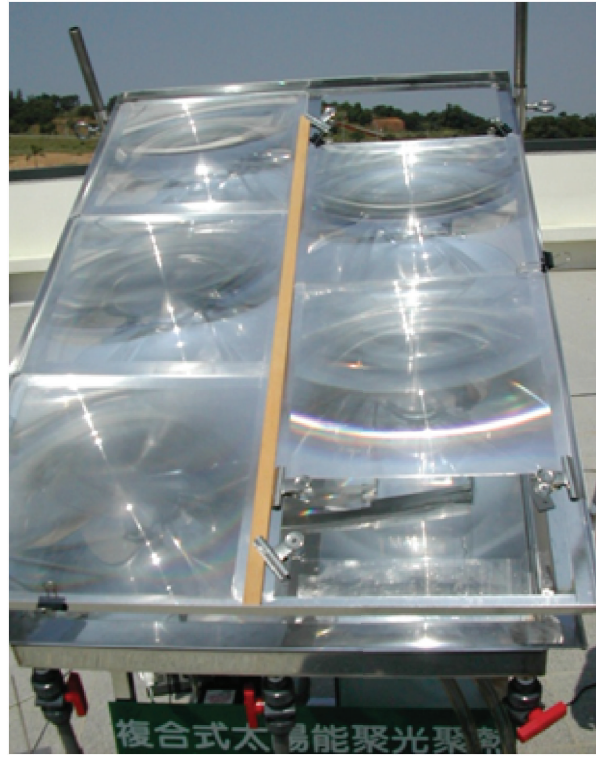

(a) With Fresnel lens

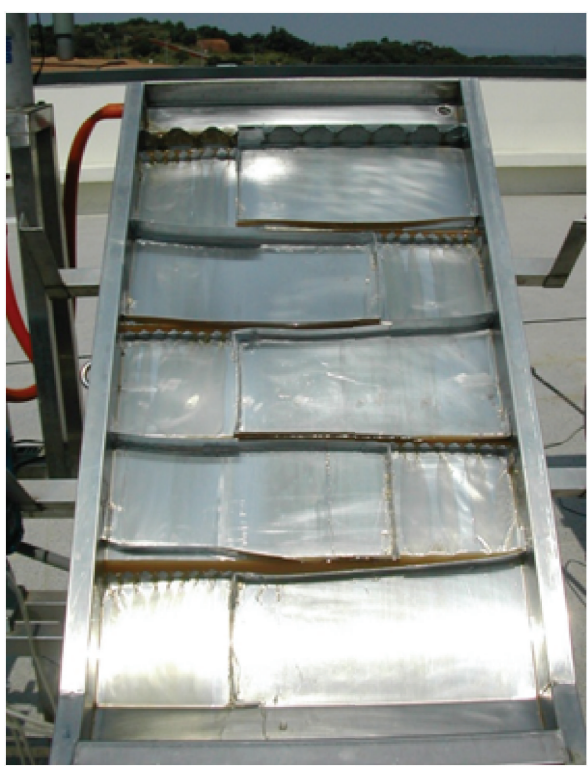

(b) Without Fresnel lens

FIGURE 1: Photograph of pilot-scale solar inclined plate curvature channel (IPCC) reactor.

lens has been proven as an appropriate concentrating device for using in solar photo-Fenton process $[7,8]$ :

$$
\begin{gathered}
\mathrm{Fe}^{2+}+\mathrm{H}_{2} \mathrm{O}_{2} \longrightarrow \mathrm{Fe}^{3+}+{ }^{\circ} \mathrm{OH}+\mathrm{OH}^{-} \\
\mathrm{Fe}^{3+}+\mathrm{H}_{2} \mathrm{O} \longrightarrow \mathrm{Fe}(\mathrm{OH})^{2+}+\mathrm{H}^{+} \\
\mathrm{Fe}(\mathrm{OH})^{2+}+h \nu \longrightarrow \mathrm{Fe}^{2+}+{ }^{\cdot} \mathrm{OH}
\end{gathered}
$$

In this study, a pilot-scale Fresnel lens mounted inclined plate curvature channel (IPCC) reactor was well designed, established, and evaluated for treatment of the electro-optical industry wastewater in different seasons.

\section{Material and Methods}

2.1. Materials. The industry wastewater used in this study was obtained from an electro-optical industry plant located in Miao-Li, Taiwan, during 2010-2012. The characteristics of electro-optical industry wastewater are shown in Table 1. Basically, the wastewater has the properties of high $\mathrm{pH}$ (10.7-11.2), COD (563-593 mg/L), and TOC (174-180 mg/L). Hydrogen peroxide $\left(\mathrm{H}_{2} \mathrm{O}_{2}\right)$ with a concentration of $35 \%$ was supplied by Panreac Co., EU. $\mathrm{FeSO}_{4} \cdot 7 \mathrm{H}_{2} \mathrm{O}$ (Panreac Co., EU) with a purity of $99 \%$ was used as a source of ferrous ion. All other chemicals used in this study were analytical grade and used as received.

2.2. Procedures. All experiments were carried out in a pilotscale Fresnel lens (5 Fresnel lens, which was made of PMMA with a thickness of $2 \mathrm{~mm}$, a pitch of $0.5 \mathrm{~mm}$, a facet depth of $0.2 \mathrm{~mm}$, and Fresnel circles of 395 were used) mounted inclined plate curvature channel (IPCC) reactor (Figure 1). The distance between Fresnel lens and inclined plate is $16 \mathrm{~cm}$.
TABLE 1: Characteristics of electro-optical industry wastewater.

\begin{tabular}{lc}
\hline Item & Range \\
\hline $\mathrm{pH}$ & $10.76 \sim 11.24$ \\
$\mathrm{UV}_{254}$ & $0.770 \sim 0.801$ \\
$\mathrm{COD}, \mathrm{mg} / \mathrm{L}$ & $563 \sim 593$ \\
$\mathrm{TOC}, \mathrm{mg} / \mathrm{L}$ & $174.1 \sim 180.3$ \\
$\mathrm{SS}, \mathrm{mg} / \mathrm{L}$ & $0.67 \sim 2.17$ \\
Color (ADMI value) & $507 \sim 565$ \\
\hline
\end{tabular}

TABLE 2: Average light intensity and temperature of different seasons in Miao-Li, Taiwan.

\begin{tabular}{lccc}
\hline Light range & Summer-Sep. & Winter-Feb. & Spring-May \\
\hline $\mathrm{VIS}, \mathrm{W} / \mathrm{m}^{2}$ & 749.8 & 711.2 & 817 \\
$\mathrm{UV}_{\mathrm{a}+\mathrm{b}}, \mathrm{W} / \mathrm{m}^{2}$ & 39.92 & 35.18 & 39.91 \\
$\mathrm{UV}_{\mathrm{a}}, \mathrm{W} / \mathrm{m}^{2}$ & 39.58 & 36.54 & 38.16 \\
$\mathrm{UV}_{365}, \mathrm{~W} / \mathrm{m}^{2}$ & 8.41 & 7.5 & 8 \\
$\mathrm{UV}_{254}, \mathrm{~W} / \mathrm{m}^{2}$ & 5.14 & 3.54 & 3.8 \\
\hline Temp. ${ }^{\circ} \mathrm{C}$ & 33.9 & 26 & 34.66 \\
\hline
\end{tabular}

An $8 \mathrm{~L}$ of the electro-optical industry wastewater was used for each experiment with an initial $\mathrm{pH}$ of 3.0 , a $\left[\mathrm{H}_{2} \mathrm{O}_{2}\right]_{0} / \mathrm{COD}_{0}$ ratio of $2.0 \mathrm{~g} / \mathrm{g}$, and a $\left[\mathrm{H}_{2} \mathrm{O}_{2}\right]_{0} /\left[\mathrm{Fe}^{2+}\right]_{0}$ ratio of 7.5 (i.e., an initial $\mathrm{H}_{2} \mathrm{O}_{2}$ dosage of $1173 \mathrm{mg} / \mathrm{L}(34.5 \mathrm{mM})$; an initial $\mathrm{Fe}^{2+}$ dosage of $256 \mathrm{mg} / \mathrm{L}(4.6 \mathrm{mM})$ ) for a reaction time of $60 \mathrm{~min}$, which was on the basis of the results from a previous study with $3 * 3 \mathrm{RSM}$ central composite design experiments [9]. During the experiments, the $\mathrm{pH}$ of the solution was monitored using a pH meter (SP-701LI 120, Suntex Co., Taiwan) equipped with a glass electrode. Samples were withdrawn from the reactor at preset time intervals, quenched 
TABLE 3: Effect of Fresnel lens on the light amplification of IPCC in different seasons.

\begin{tabular}{lccc}
\hline Light range & & Amplification of light intensity & Spring-May \\
\hline VIS & Summer-Sep. & Winter-Feb. & $>2$ \\
$\mathrm{UV}_{\mathrm{a}+\mathrm{b}}$ & 3.76 & 1.89 & 2.55 \\
$\mathrm{UV}_{\mathrm{a}}$ & 3.86 & 1.74 & 2.64 \\
$\mathrm{UV}_{365}$ & 3.28 & 1.74 & 2.76 \\
$\mathrm{UV}_{254}$ & 3.35 & 1.83 & 2.74 \\
\hline
\end{tabular}

TABLE 4: Effect of Fresnel lens on IPCC for treatment of the electro-optical industry wastewater in different seasons.

\begin{tabular}{|c|c|c|c|c|c|c|}
\hline Condition & ${ }^{\mathrm{a}} k_{\mathrm{COD}}, \min ^{-1}$ & ${ }^{\mathrm{c}} r^{2}$ & Fresnel lens effect & ${ }^{\mathrm{b}} k_{\mathrm{TOC}}, \min ^{-1}$ & ${ }^{\mathrm{c}} r^{2}$ & Fresnel lens effect \\
\hline $\begin{array}{l}\text { With Fresnel lens } \\
\text { (Summer-Sep.) }\end{array}$ & 0.056 & 0.958 & 1.7 & 0.018 & 0.964 & 1.20 \\
\hline $\begin{array}{l}\text { Without Fresnel lens } \\
\text { (Summer-Sep.) }\end{array}$ & 0.033 & 0.906 & - & 0.015 & 0.969 & - \\
\hline $\begin{array}{l}\text { With Fresnel lens } \\
\text { (Spring_May) }\end{array}$ & 0.046 & 0.944 & 1.44 & 0.015 & 0.975 & 1.07 \\
\hline $\begin{array}{l}\text { Without Fresnel lens } \\
\text { (Spring-May) }\end{array}$ & 0.032 & 0.915 & - & 0.014 & 0.955 & - \\
\hline $\begin{array}{l}\text { With Fresnel lens } \\
\text { (Winter-Feb.) }\end{array}$ & 0.024 & 0.907 & 1.04 & 0.007 & 0.937 & 1.4 \\
\hline $\begin{array}{l}\text { With Fresnel lens } \\
\text { (Winter-Feb.) }\end{array}$ & 0.023 & 0.900 & - & 0.005 & 0.962 & - \\
\hline
\end{tabular}

* Operation condition: $\mathrm{pH}_{0}: 3.0,2.0 \mathrm{~g} \mathrm{H}_{2} \mathrm{O}_{2} / \mathrm{g} \mathrm{COD},\left[\mathrm{H}_{2} \mathrm{O}_{2}\right]_{0} /\left[\mathrm{Fe}^{2+}\right]_{0}=7.5$.

${ }^{\mathrm{a}} k_{\mathrm{COD}}$ : pseudo-first order rate constant based on the degradation of COD in solution.

${ }^{\mathrm{b}} k_{\mathrm{TOC}}$ : pseudo-first order rate constant based on the degradation of TOC in solution.

${ }^{c} r^{2}$ : coefficient of determination.

with sodium hydrogen sulfite to avoid further reactions, then tested for $\mathrm{H}_{2} \mathrm{O}_{2}$ consumption according to the method reported by Sellers [10] and iron as $\mathrm{Fe}^{2+}$ ion is determined by $\mathrm{Fe}(\mathrm{II}) / 1,10$-phenanthroline complex at $510 \mathrm{~nm}$ [11] using a Hitachi (Japan) U-2001 spectrophotometer instantly. The remaining samples were then stored at $4^{\circ} \mathrm{C}$ for the following COD, TOC, and microtoxicity analysis.

The solar irradiation was measured with a LI-250 radiation indicator (LI-COR Co., USA) of pyranometer LI-200SA and a $\mathrm{UV}_{280-400 \mathrm{~nm}}$ detector of PMA 2100 (Solar Light Co., USA).

\subsection{Analysis}

2.3.1. Chemical Oxygen Demand (COD) Measurement. COD of solution via a DR 4000 photometer (HACH Co., USA) by using a $\mathrm{K}_{2} \mathrm{Cr}_{2} \mathrm{O}_{7}$ as the reacting reagent was measured in order to understand the changes of degree of oxidation for color filter wastewater.

2.3.2. Total Organic Carbon (TOC) Measurement. TOC of solution was measured by using a Shimadzu VCPH analyzer (Shimadzu Co., Japan) in order to know the amount of organics in color filter wastewater degraded to $\mathrm{CO}_{2}$ during oxidation.

2.3.3. Microtoxicity Measurement. The microtoxicity of each sample was measured using an SDI M500 (SDI Co., USA) analyzer. Microtoxicity is expressed as $\mathrm{EC}_{50}\left(5 \mathrm{~min}, 15^{\circ} \mathrm{C}\right)$, which was defined as the effective concentration of solution for a $50 \%$ reduction of the luminescence of the bacterium Photobacterium phosphoreum. A lower $\mathrm{EC}_{50}$ value indicates a higher amount of toxic constituent presented in the pollutant solution. The $\mathrm{EC}_{50}$ values are expressed as percentage $(\%$ $\mathrm{v} / \mathrm{v})$ of the sample $[12,13]$. In addition, $\mathrm{EC}_{50}$ values could be transformed to toxicity units $\left(\mathrm{TU}_{50}\right)$, which was equal to $1 / \mathrm{EC}_{50}$. The $\mathrm{EC}_{50}$ of electro-optical industry wastewater was measured and it was 300 400\%. Toxicity Unit $\left(\mathrm{TU}_{50}\right)$ was therefore in the range of $0.25 \sim 0.33$. In this study, the $\mathrm{TU}_{50}$ value was used to trace the change in toxicity of the electro-optical industry wastewater due to solar photoFenton treatment.

\section{Results and Discussion}

Table 2 showed the average light intensity and temperature of different seasons in Miao-Li, Taiwan. Basically, it was found that the solar light concentrating effect of Fresnel lens for IPCC reactor could result in an increase of 1.89 3.76 times of solar light irradiation $\left(\mathrm{UV}_{\mathrm{a}+\mathrm{b}}\right)$ (Table 3), which is higher than that (1.2 times) of CPC reactor [15], and a raising heat irradiation in terms of $8 \sim 16^{\circ} \mathrm{C}$ increase of wastewater temperature in this study. Figure 2 showed the effect of Fresnel lens on the $\mathrm{pH}, \mathrm{H}_{2} \mathrm{O}_{2}$ consumption, and residual $\mathrm{Fe}^{2+}$ concentration in the electro-optical industry wastewater treated by solar IPCC reactor. The observed final $\mathrm{pH}$ of 


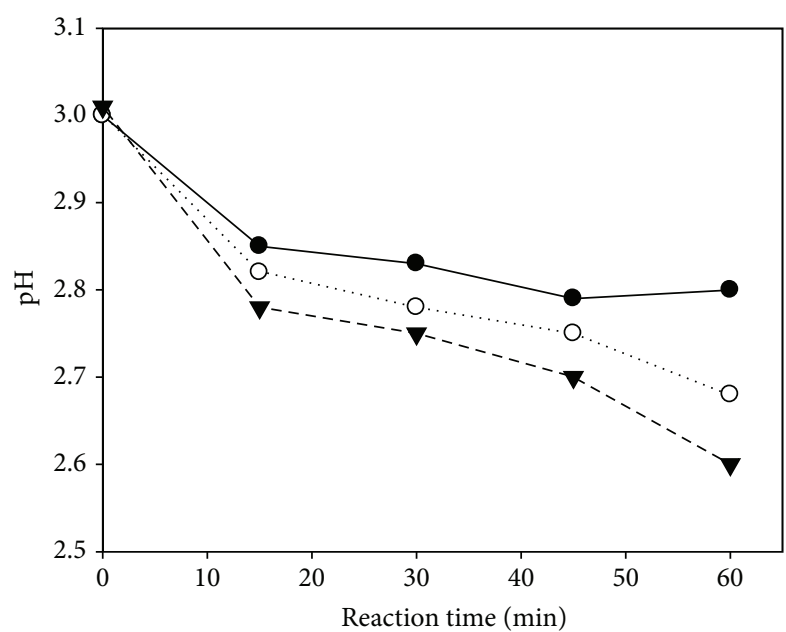

(a)

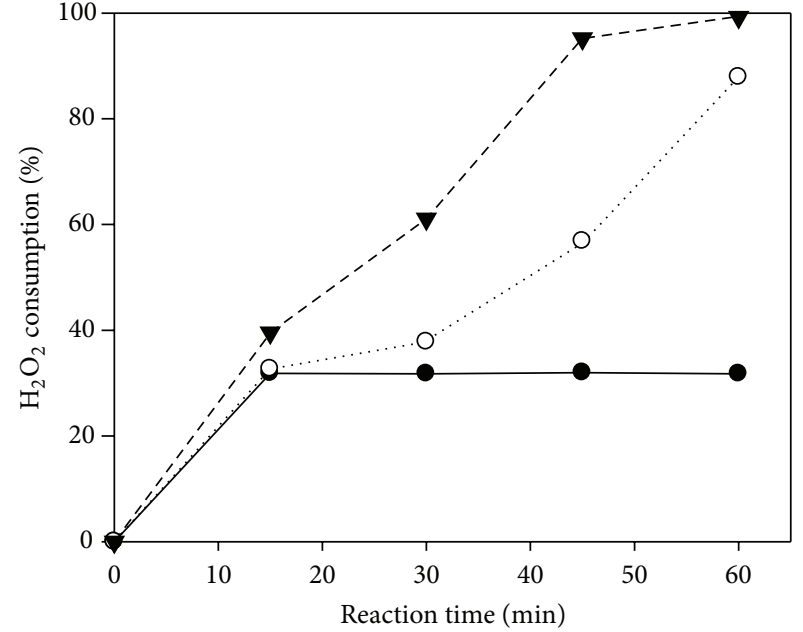

(b)

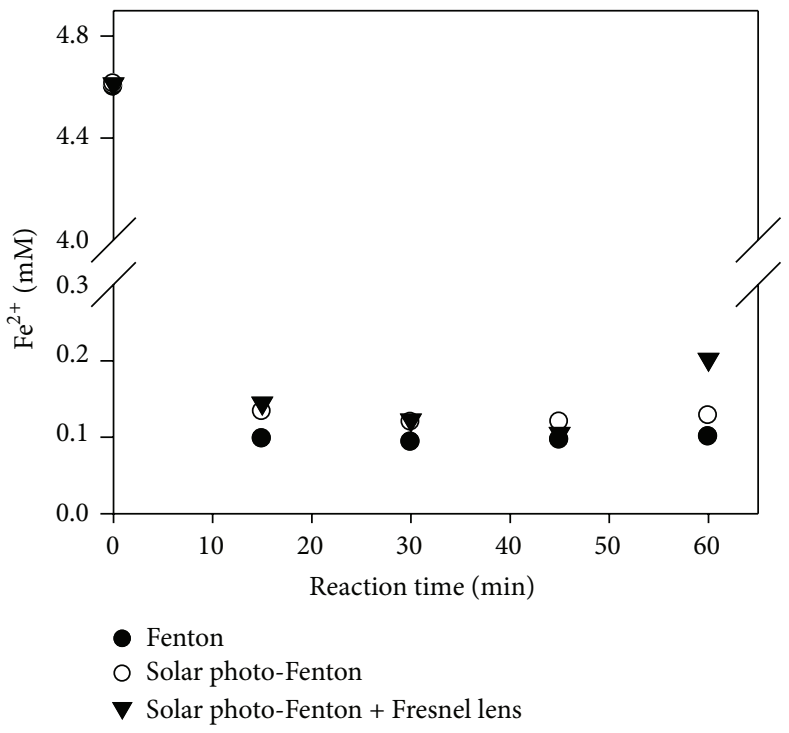

(c)

FIgURE 2: Effect of Fresnel lens on the $\mathrm{pH}, \mathrm{H}_{2} \mathrm{O}_{2}$ consumption, and residual $\mathrm{Fe}^{2+}$ concentration in the electro-optical industry wastewater treated by solar IPCC reactor (initial pH: 3.0; $\left[\mathrm{H}_{2} \mathrm{O}_{2}\right]_{0} / \mathrm{COD}_{0}=2.0 \mathrm{~g} / \mathrm{g} ;\left[\mathrm{H}_{2} \mathrm{O}_{2}\right]_{0} /\left[\mathrm{Fe}^{2+}\right]_{0}=7.5$ ).

TABLE 5: Comparisons of operation performance for compound parabolic collecting reactor (CPC), falling film reactor (FFR), and inclined plate curvature channel (IPCC) reactor.

\begin{tabular}{|c|c|c|c|c|c|c|c|}
\hline Reactor type & $\begin{array}{c}\text { Waste-water } \\
\text { type and vol. (L) }\end{array}$ & $\begin{array}{l}\text { Radiation area } \\
\text { on reactor }\left(\mathrm{m}^{2}\right)\end{array}$ & $\begin{array}{l}\text { Reaction } \\
\text { time }(\mathrm{h})\end{array}$ & $\begin{array}{l}\text { Accumulation } \\
\text { irradiated } \\
\text { energy }(\mathrm{kJ} / \mathrm{L} * \mathrm{~h})\end{array}$ & $\begin{array}{l}\text { Initial COD } \\
\quad(\mathrm{mg} / \mathrm{L})\end{array}$ & $\begin{array}{c}\text { Final COD } \\
(\mathrm{mg} / \mathrm{L})\end{array}$ & $\begin{array}{c}\text { Operation } \\
\text { dosage }\end{array}$ \\
\hline CPC [14] & $\begin{array}{c}\text { Olive mill } \\
\text { waste-water } 30 \mathrm{~L}\end{array}$ & 3.08 & 12 & 11.42 & 3400 & 1700 & $\begin{array}{c}{\left[\mathrm{H}_{2} \mathrm{O}_{2}\right]_{0}=} \\
5000 \mathrm{mg} / \mathrm{L} \\
{\left[\mathrm{Fe}^{2+}\right]_{0}=5 \mathrm{mM}}\end{array}$ \\
\hline FFR [14] & $\begin{array}{c}\text { Olive mill } \\
\text { waste-water } 19 \mathrm{~L}\end{array}$ & 1 & 14 & 5.64 & 3000 & 1700 & $\begin{array}{c}{\left[\mathrm{H}_{2} \mathrm{O}_{2}\right]_{0}=} \\
5000 \mathrm{mg} / \mathrm{L} \\
{\left[\mathrm{Fe}^{2+}\right]_{0}=5 \mathrm{mM}}\end{array}$ \\
\hline IPCC (this study) & $\begin{array}{l}\text { Electro-optical } \\
\text { industry } \\
\text { waste-water } 8 \mathrm{~L}\end{array}$ & 0.12 & 1 & 7.45 & 588 & 44 & $\begin{array}{c}{\left[\mathrm{H}_{2} \mathrm{O}_{2}\right]_{0}=} \\
1173 \mathrm{mg} / \mathrm{L} \\
{\left[\mathrm{Fe}^{2+}\right]_{0}=} \\
4.6 \mathrm{mM}\end{array}$ \\
\hline
\end{tabular}



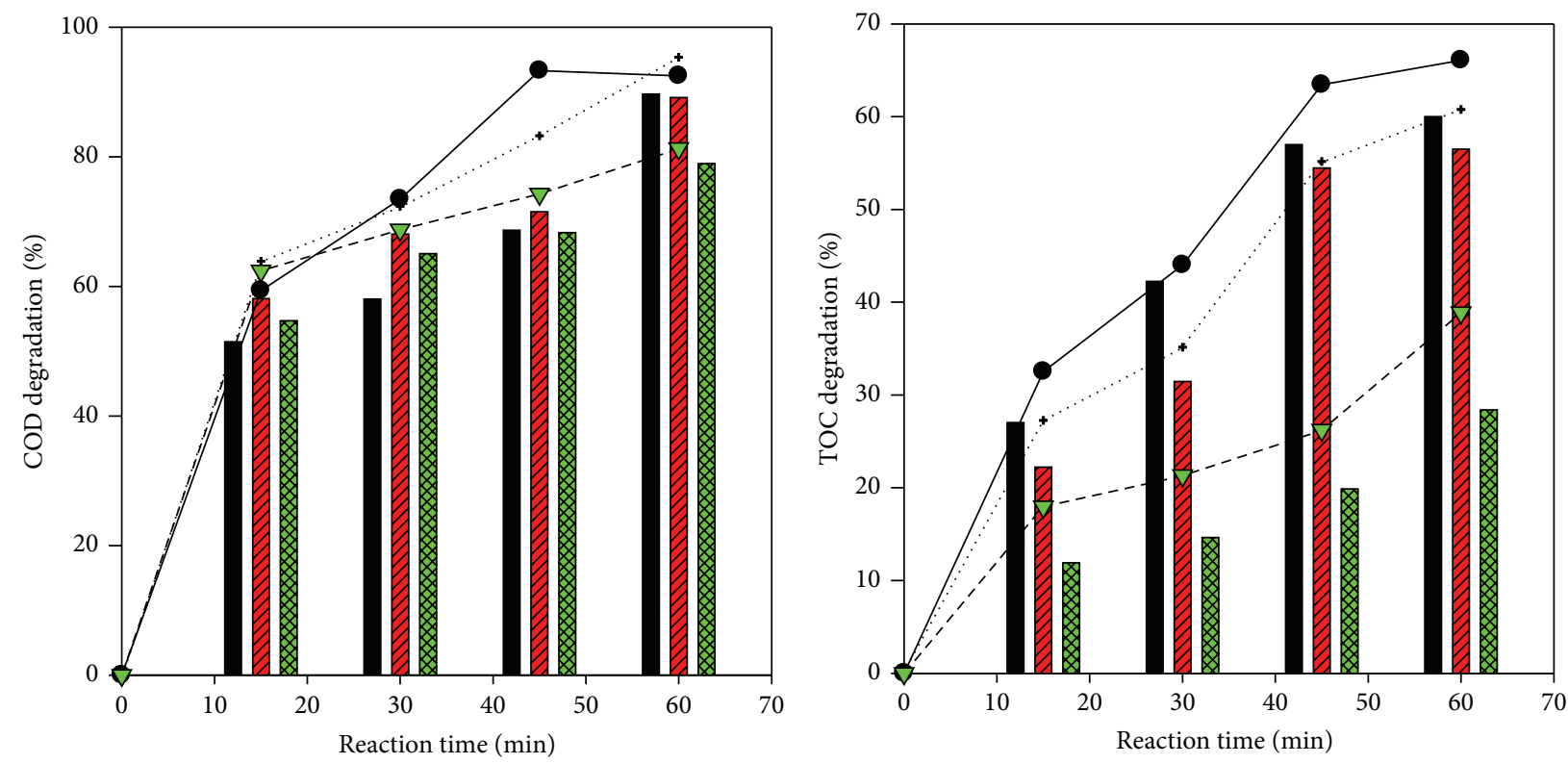

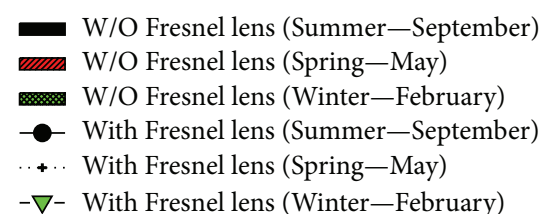

(a)

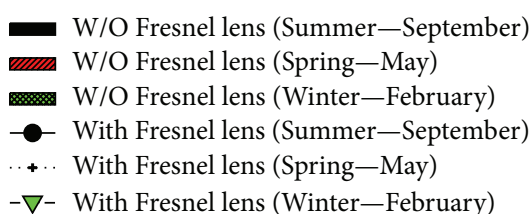

(b)

FIGURE 3: Effect of Fresnel lens on the degradation efficiency of (a) COD and (b) TOC of electro-optical industry wastewater treated by solar IPCC reactor in different seasons (initial pH: 3.0; $\left[\mathrm{H}_{2} \mathrm{O}_{2}\right]_{0} / \mathrm{COD}_{0}=2.0 \mathrm{~g} / \mathrm{g} ;\left[\mathrm{H}_{2} \mathrm{O}_{2}\right]_{0} /\left[\mathrm{Fe}^{2+}\right]_{0}=7.5$ ).

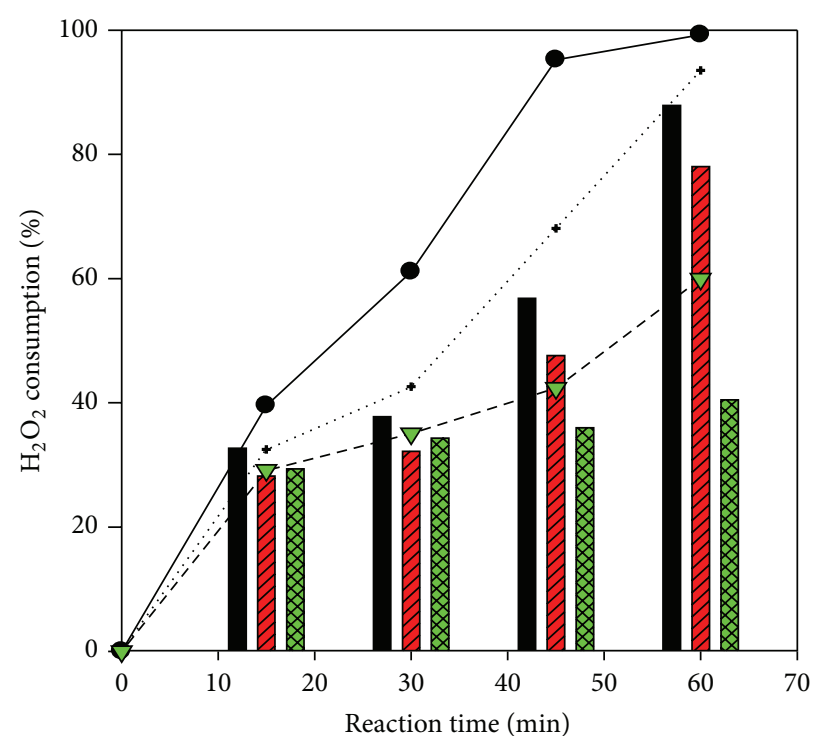

W/O Fresnel lens (Summer-September)
W/O Fresnel lens (Spring-May)
W/O Fresnel lens (Winter-February)
- With Fresnel lens (Summer-September)
$-\cdots$ With Fresnel lens (Spring-May)
$-\nabla-$ With Fresnel lens (Winter-February)

(a)

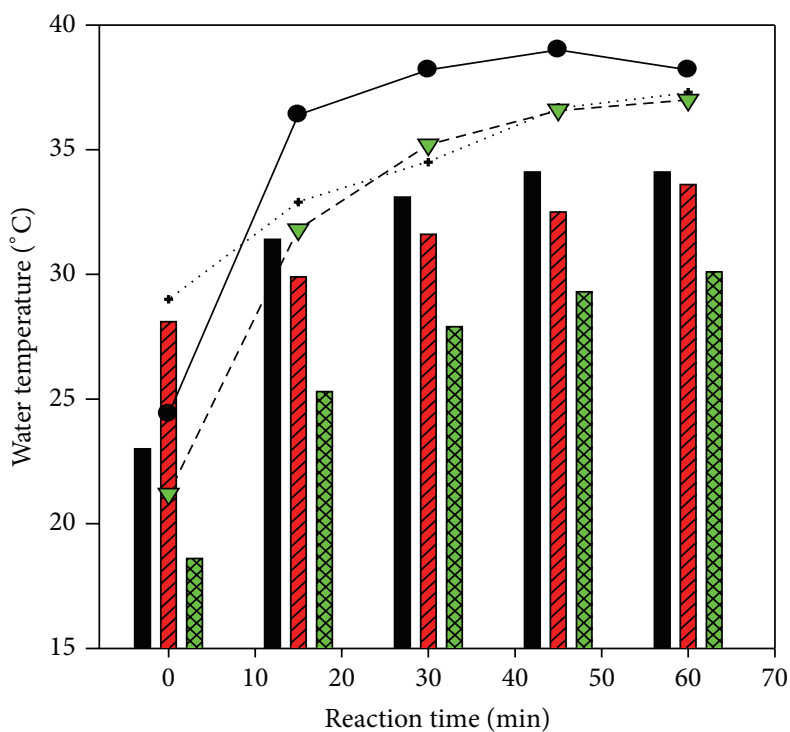

W/O Fresnel lens (Summer-September)

mom W/O Fresnel lens (Spring-May)

W/O Fresnel lens (Winter-February)

- With Fresnel lens (Summer-September)

... With Fresnel lens (Spring-May)

$-\nabla$ - With Fresnel lens (Winter-February)

(b)

FIGURE 4: $\mathrm{H}_{2} \mathrm{O}_{2}$ consumption (a) and water temperature (b) of the electro-optical industry wastewater treated by solar IPCC reactor in different seasons (initial pH: 3.0; $\left[\mathrm{H}_{2} \mathrm{O}_{2}\right]_{0} / \mathrm{COD}_{0}=2.0 \mathrm{~g} / \mathrm{g}$; $\left[\mathrm{H}_{2} \mathrm{O}_{2}\right]_{0} /\left[\mathrm{Fe}^{2+}\right]_{0}=7.5$ ). 
the treated wastewater was around 2.6-2.8. With the assistance of Fresnel lens, IPCC reactor had a higher $\mathrm{H}_{2} \mathrm{O}_{2}$ consumption efficiency due to a higher residual $\mathrm{Fe}^{2+}$ concentration to react with $\mathrm{H}_{2} \mathrm{O}_{2}$. Moreover, Figure 3 showed the effect of Fresnel lens on the COD and TOC degradation efficiency of the electro-optical industry wastewater by solar IPCC reactor in different seasons. As shown in Figure 3, the COD of the wastewater could have a reduction of 85$90 \%$ and reach the effluent standard of EPA, Taiwan (COD $<100 \mathrm{mg} / \mathrm{L}$ ), within a reaction of $60 \mathrm{~min}$. An increase in COD degradation of $6-20 \%$ and a TOC degradation of 5$20 \%$ of the electro-optical industry wastewater were reached with the assistance of Fresnel lens. Also, it was found that the degradation efficiency of the electro-optical industry wastewater with the use of Fresnel lens at a reaction time of 45 min was higher than that without the assistance of Fresnel lens at a reaction time of $60 \mathrm{~min}$ in summer season (Sep.). This could be due to a higher light irradiation and water temperature increased the consumption of $\mathrm{H}_{2} \mathrm{O}_{2}$ as shown in Figure 4, that is, increasing the reaction rate between hydrogen peroxide and any form of ferrous/ferric ion, thus increased the rate of generation of oxidizing species such as ${ }^{\circ} \mathrm{OH}$ radical [16]. Furthermore, the microtoxicity $\left(\mathrm{TU}_{50}\right)$ of electro-optical industry wastewater decreased almost to 0 as the reaction proceeded only $15 \mathrm{~min}$ for each season, indicating that the treated wastewater was essentially nontoxic. A similar phenomenon was also found in the study of Will et al. [17]. Its result indicated that the TOC degradation efficiency of phenol wastewater was $45 \%$ and $55 \%$ for a solar irradiation of $450 \mathrm{~W} / \mathrm{m}^{2}$ and $750 \mathrm{~W} / \mathrm{m}^{2}$, respectively. In addition, Rodriguez et al. [18] also showed that the degradation efficiency of textile wastewater increased, while the temperature of water was raised obviously from $30^{\circ} \mathrm{C}$ to $60^{\circ} \mathrm{C}$ in photo-Fenton process.

To quantitatively analyze the effect of Fresnel lens on the degradation rate of electro-optical industry wastewater treated by solar IPCC reactor in different seasons, a pseudofirst order model expressed by (4) was applied to obtain the rate constants:

$$
-\frac{d C}{d t}=k C,
$$

in which $C$ is the concentration of COD or TOC in solution at time $t$ and $k$ is the pseudo-first order rate constant. It was found that both COD and TOC degradation rate of the electro-optical industry wastewater with or without Fresnel lens followed the pseudo-first order reaction kinetics as indicated by a high determination coefficient $\left(r^{2}>\right.$ 0.90) (Table 4). It was found that an enhancement for the degradation rate of electro-optical industry wastewater was observed by the aid of Fresnel lens. In summer season, the COD and TOC degradation rate of the electro-optical industry wastewater was increased by a factor of 1.7 and 1.2, respectively.

Furthermore, in order to evaluate precisely the operation performance of IPCC, a comparison among IPCC, compound parabolic collecting reactor (CPC) [14], and falling film reactor (FFR) [14] was made as shown in Table 5. It was found that IPCC had a greater COD degradation efficiency as compared to CPC and FFR reactors even though the accumulation irradiated energy per liter wastewater of IPCC $(7.45 \mathrm{~kJ} / \mathrm{L} * \mathrm{~h})$ was lower than that $(11.42 \mathrm{~kJ} / \mathrm{L} * \mathrm{~h})$ of CPC.

\section{Conclusions}

With the treatment of Fresnel lens assisted solar IPCC reactor, the COD of the wastewater could reach a reduction of $85-90 \%$ and meet the effluent standard of EPA, Taiwan $(\mathrm{COD}<100 \mathrm{mg} / \mathrm{L})$, after a $60 \mathrm{~min}$ treatment even in winter season. Moreover, the residual COD of the treated wastewater was below $100 \mathrm{mg} / \mathrm{L}$ for a merely $45 \mathrm{~min}$ treatment, and a COD degradation efficiency of $93 \%$ and a mineralization efficiency of $65 \%$ in summer/autumn season (September) could be reached. Accordingly, these results illustrated that the well designed Fresnel lens assisted IPCC reactor showed a synergistic effect on the solar photo-Fenton process not only in effectively dealing with a large amount of industrial organic wastewater, but also in the sector of energy conservation in terms of effective utilization of solar energy.

\section{Acknowledgment}

Many thanks to the kind sponsorship of National Science Council, Taiwan (Project no.: NSC 99-2221-E-239-011), without which this work would not have been possible.

\section{References}

[1] F. Al Momani, O. Gonzalez, C. Sans, and S. Esplugas, "Combining photo-Fenton process with biological sequencing batch reactor for 2,4-dichlorophenol degradation," Water Science and Technology, vol. 49, no. 4, pp. 293-298, 2004.

[2] L. A. Pérez-Estrada, S. Malato, A. Agüera, and A. R. FernándezAlba, "Degradation of dipyrone and its main intermediates by solar AOPs. Identification of intermediate products and toxicity assessment," Catalysis Today, vol. 129, no. 1-2, pp. 207-214, 2007.

[3] M. I. Maldonado, P. C. Passarinho, I. Oller et al., "Photocatalytic degradation of EU priority substances: a comparison between $\mathrm{TiO}_{2}$ and Fenton plus photo-Fenton in a solar pilot plant," Journal of Photochemistry and Photobiology A, vol. 185, no. 2-3, pp. 354-363, 2007.

[4] S. Malato, P. Fernández-Ibáñez, M. I. Maldonado, J. Blanco, and W. Gernjak, "Decontamination and disinfection of water by solar photocatalysis: recent overview and trends," Catalysis Today, vol. 147, no. 1, pp. 1-59, 2009.

[5] J. M. Monteagudo and A. Durán, "Fresnel lens to concentrate solar energy for the photocatalytic decoloration and mineralization of orange II in aqueous solution," Chemosphere, vol. 65, no. 7, pp. 1242-1248, 2006.

[6] V. J. P. Vilar, S. M. S. Capelo, T. F. C. V. Silva, and R. A. R. Boaventura, "Solar photo-Fenton as a pre-oxidation step for biological treatment of landfill leachate in a pilot plant with CPCs," Catalysis Today, vol. 161, no. 1, pp. 228-234, 2011.

[7] J. M. Monteagudo, A. Durán, J. Guerra, F. García-Peña, and P. Coca, "Solar $\mathrm{TiO}_{2}$-assisted photocatalytic degradation of IGCC power station effluents using a Fresnel lens," Chemosphere, vol. 71, no. 1, pp. 161-167, 2008.

[8] W. S. Kuo and C. L. Wu, "Treatment of color filter wastewater by fresnel lens enhanced solar photo-Fenton process," Advances in 
Materials Science and Engineering, vol. 2012, Article ID 679206, 6 pages, 2012.

[9] D. Y. Liu, Treatment of color filter wastewater by a pilot-scale IPCC solar photo-Fenton reactor [M.S. thesis], National United University, Taiwan, 2012.

[10] R. M. Sellers, "Spectrophotometric determination of hydrogen peroxide using potassium titanium(IV) oxalate," The Analyst, vol. 105, no. 1255, pp. 950-954, 1980.

[11] APHA/AWWA/WEF, Standard Methods For the Examination of Water and Wastewater, Washington DC, USA, 20th edition, 2000.

[12] O. González, C. Sans, and S. Esplugas, "Sulfamethoxazole abatement by photo-Fenton. Toxicity, inhibition and biodegradability assessment of intermediates," Journal of Hazardous Materials, vol. 146, no. 3, pp. 459-464, 2007.

[13] A. S. Koparal, Y. Yavuz, C. Gürel, and U. B. Öğütveren, "Electrochemical degradation and toxicity reduction of C.I. Basic Red 29 solution and textile wastewater by using diamond anode," Journal of Hazardous Materials, vol. 145, no. 1-2, pp. 100108, 2007.

[14] W. Gernjak, M. L. Maldonado, S. Malato et al., "Pilot-plant treatment of olive mill wastewater (OMW) by solar $\mathrm{TiO}_{2}$ photocatalysis and solar photo-Fenton," Solar Energy, vol. 77, no. 5, pp. 567-572, 2004.

[15] O. M. Alfano, D. Bahnemann, A. E. Cassano, R. Dillert, and R. Goslich, "Photocatalysis in water environments using artificial and solar light," Catalysis Today, vol. 58, no. 2, pp. 199-230, 2000.

[16] J.-H. Sun, S.-P. Sun, G.-L. Wang, and L.-P. Qiao, "Degradation of azo dye Amido black 10B in aqueous solution by Fenton oxidation process," Dyes and Pigments, vol. 74, no. 3, pp. 647652, 2007.

[17] I. B. S. Will, J. E. F. Moraes, A. C. S. C. Teixeira, R. Guardani, and C. A. O. Nascimento, "Photo-Fenton degradation of wastewater containing organic compounds in solar reactors," Separation and Purification Technology, vol. 34, no. 1-3, pp. 51-57, 2004.

[18] M. Rodriguez, V. Sarria, S. Esplugas, and C. Pulgarin, "Photoenton treatment of a biorecalcitrant wastewater generated in textile activities: biodegradability of the photo-treated solution," Journal of Photochemistry and Photobiology A, vol. 151, no. 1-3, pp. 129-135, 2002. 

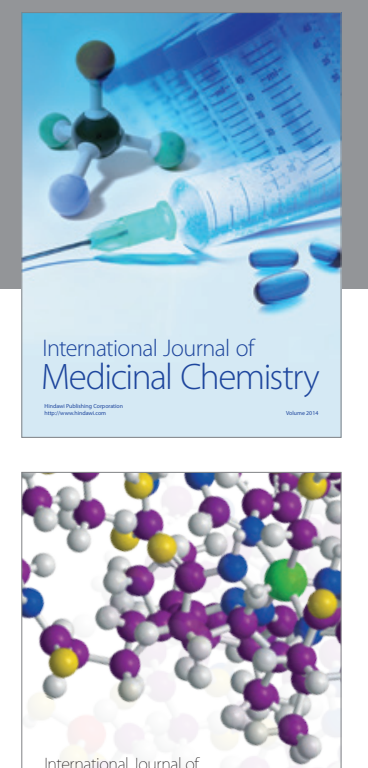

\section{Carbohydrate} Chemistry

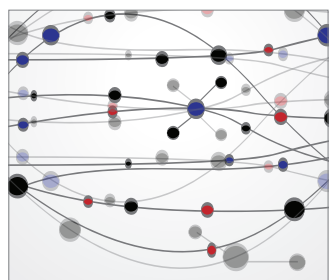

The Scientific World Journal
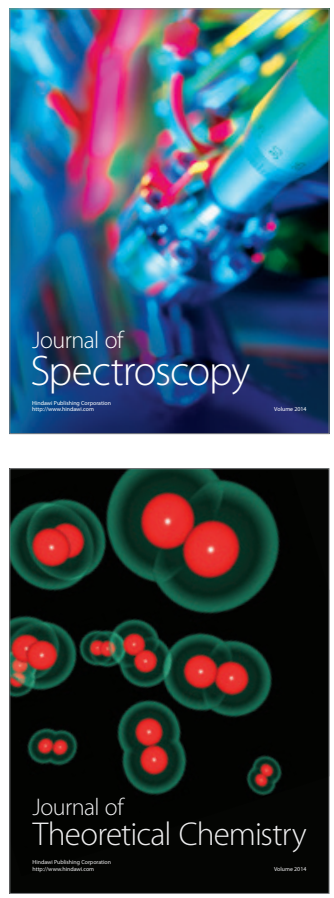
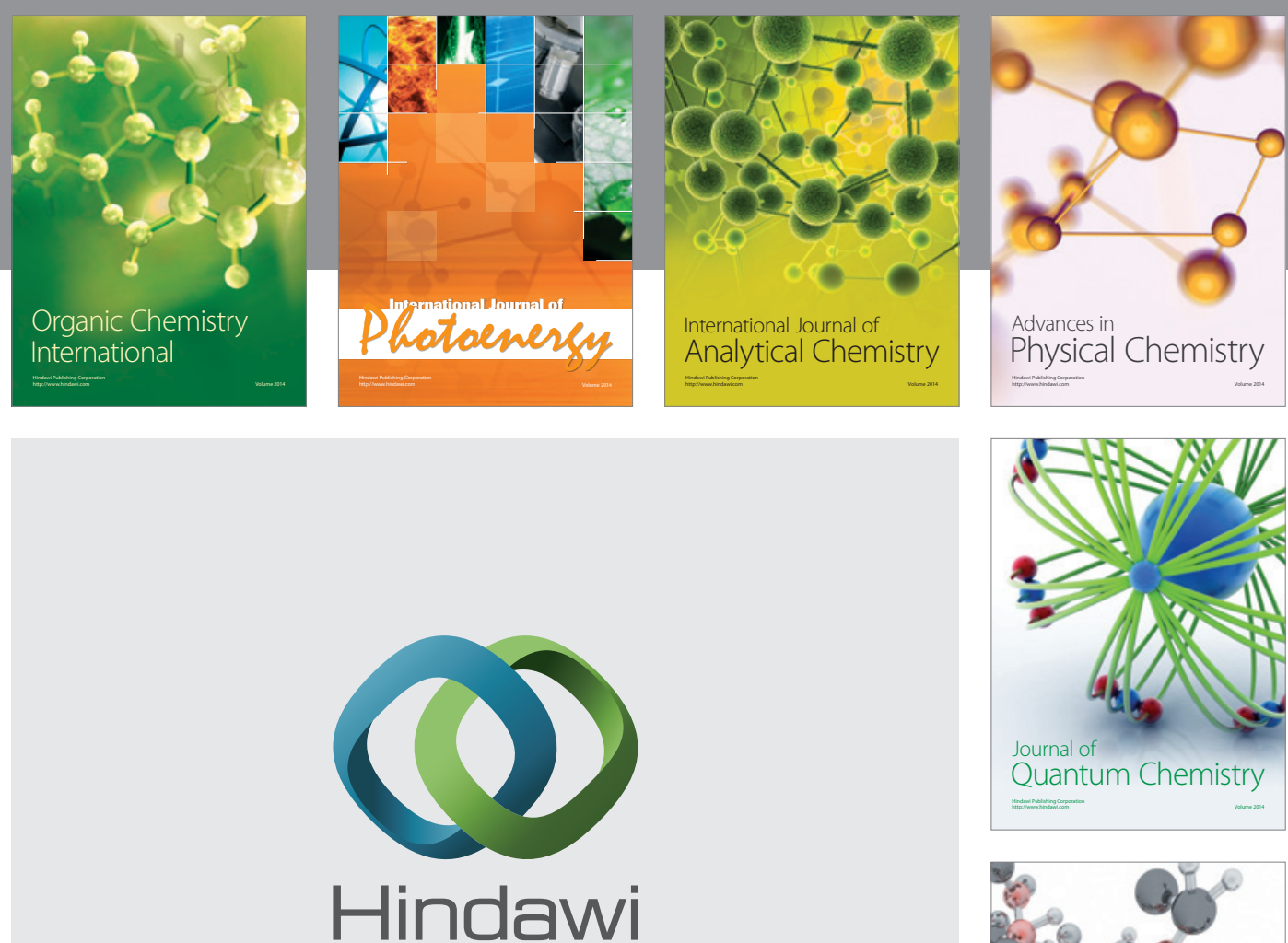

Submit your manuscripts at

http://www.hindawi.com

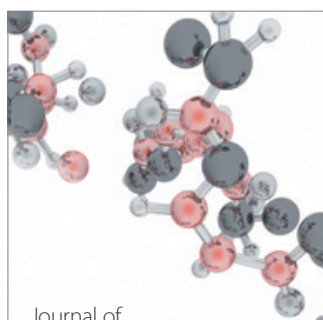

Analytical Methods

in Chemistry

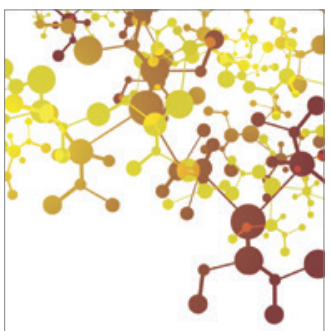

Journal of

Applied Chemistry

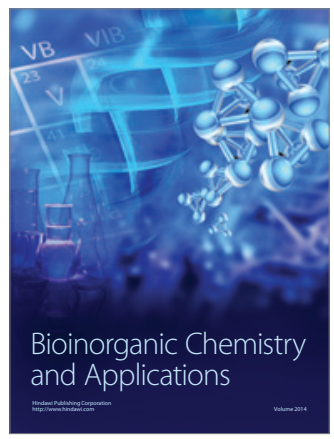

Inorganic Chemistry
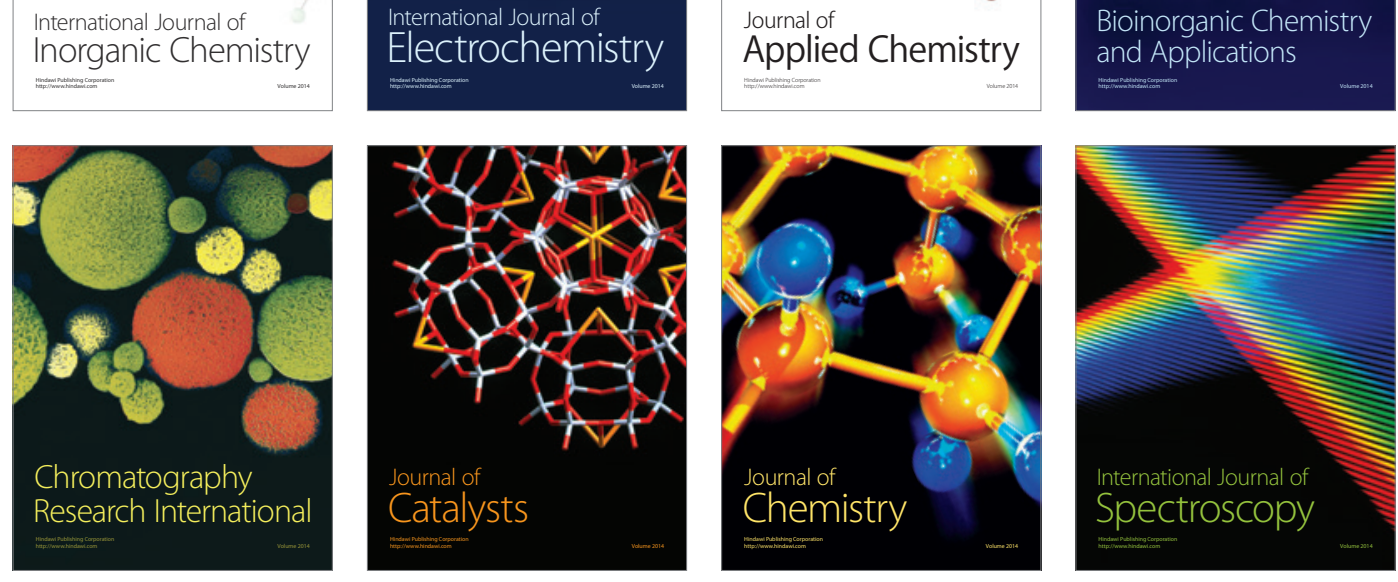